\title{
Impact analysis of excise tariff on market share of cigarette companies, during the period 2009-2015
}

\author{
D.N. Sari \& H. Susanti \\ Department of Economics, Faculty of Economics and Business, Universitas Indonesia, Depok, Indonesia
}

\begin{abstract}
This research analyses the correlation between excise rates and cigarette companies in Indonesia recorded in the Directorate General of Customs and Excise. In order to find out how the market shapes the cigarette industry, the analysis was done using structure - conduct - performance frame work, that looked at the relationship of structure, behaviour, and performance in the cigarette industry. The cigarette industry in Indonesia has an oligopoly structure with a moderate level of competition. Of the two models in all companies, it has been found that the application of tax rates is significantly and negatively associated with the cigarette companies' market share and the sale price of cigarettes. The population growth of individuals aged 15-24 years has a positive and sinifcant impact on the cigarette market share. Meanwhile, for the five major companies, the other model (those a fed 15 years and above) has found that excise per selling price has a positive effect on the market share.
\end{abstract}

\section{INTRODUCTION}

A number of studies are correlating cancer with cigarette consumption making the global community try to reduce the rate of cigarette consumption through various health and tax policies. Cigarettes have an addictive substance and consumption of these products should be controlled. In Indonesia, under Article 2 of Law No. 39/2007 on excise, cigarettes qualify as goods subject to excise.

The government continues to increase tobacco excise rates significantly, reaching its upper limit of $57 \%$ of the retail price. In addition, the excise rates in Indonesia are still low compared with those of other developing or poor countries. In 2014, the proportion of taxes to cigarettes price in Indonesia was only $53.4 \%$, compared with $73.13 \%$ in Thailand (Djoko, 2013). Since 2009, excise imposition of cigarettes in Indonesia has been set at a specific tariff, based on the type of cigarettes, class production, production restrictions, and limitations of the retail price. Tobacco products are divided into three types (1) clove cigarettes machine or sigaret kretek mesin (SKM) (2) white cigarettes machine or sigaret putih mesin (SPM), and (3) hand-rolled clove cigarettes or sigaret kretek tangan (SKT). Among these, the largest excise tariff is imposed on SKM, about $10 \%$ higher than the average tax rates on SPM and nearly three times the average SKT customs tariff.

In terms of the manufacturer, excise is viewed as a threat to business as it can reduce a company's profitability following the shrinking of people's buying power. To prevent the hike of excise tariff, the industry has also stated that tax has made the number of unemployed in this sector increase. However, on the other hand, the demand of cigarette products continues to increase each year, although a decrease was recorded in 2013-14 (see Figure 1).

Currently, the industry is producing SKM more than the two other cigarette types. Sumarno \& Kuncoro (2002) state that the market domination among big players in the cigarette industry, such as PT Gudang Garam Tbk, PT HM Sampoerna Tbk, and PT Djarum, started to shift their production from SKT to SKM since the end of the 1990s. This can be seen by the increased SKM production in those companies. 


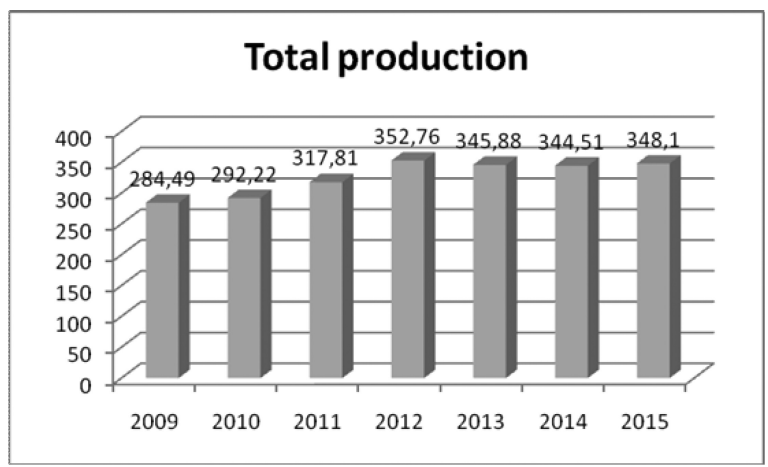

Figure 1. Cigarette production in Indonesia (in billion pieces), Source: Ministry of Finance, Indonesia.

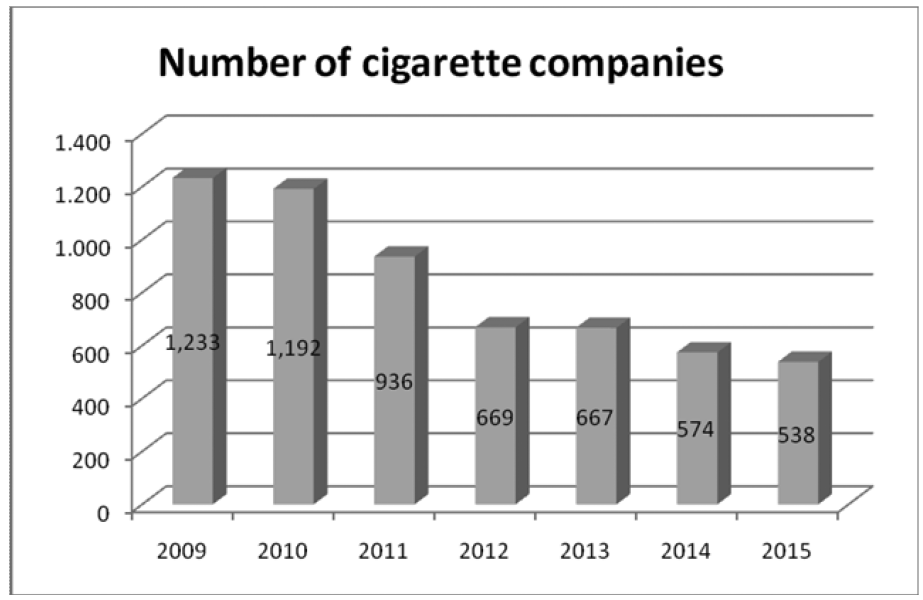

Figure 2. Number of cigarette companies in Indonesia, 2009-15. Source: Ministry of Finance, Indonesia.

On the other hand, a continual decline in the number of manufacturers was considered as the result of tax rates hike (see Figure 2). From 2009 to 2015, the decline in the number of companies was significant. Based on the data from the Directorate General of Customs and Excise, there were 88 companies in 2015, down from 1,233 companies in 2009. In order to survive, not infrequently, small cigarette companies make false excise bands so that the cigarettes are not imposed by excise and become illegal.

\section{THEORETICAL FRAMEWORK}

To explore the problems presented in this study, a structure - conduct - performance framework was used for analysis along with factors that affect the market share of a company, the price of goods themselves, the amount of production, and many types of products/services offered (Tauraz \& Chaolupka, 2006; Babic \& Kalic, 2014).

The increase in cigarette prices does not reduce the consumption of tobacco, but changes the pattern of cigarette consumption. Based on the consumption patterns of smokers, non-SKM cigarettes are a substitution of non-SPM goods. Meanwhile, the price of SPM cigarettes has a positive influence on demand for SKT cigarettes, where the SPM 
price increase causes an increase in demand of non-SKT products (Rudi, 2004: Herlambang, 2005).

In addition to the price, advertising is also believed to have an important role in the cigarette market share. As many as $60 \%$ of smokers start smoking at the age of 13 years. Children generally recognise cigarette brands from sports events on television that are sponsored by tobacco companies. Cigarette brands that often sponsor sports events are more likely to be chosen by teenagers to consume the cigarettes (Arnett \& Terhanian, 1998; Bates \& Rowell, 2012).

\section{METHODOLOGY AND DATA}

Data processing was done by using the structure - conduct-performance framework to determine the impact of policies that affect the tax structure, conduct, and performance of companies in the tobacco industry. We also conducted econometric measurements to determine the relationship between tax rates and corporate concentration.

The equation econometric model was estimated using the panel data balance. For data collection, first, nine companies were identified in the cigarette market of 2009-15 based on the classification in the application of specific tax rates. Five companies with the largest production, one company with more than 2 billion cigarettes, one with more than 350 million cigarettes and fewer than 2 billion tobaccos, one with more than 50 million cigarettes but not 350 million rods, and one with fewer than 50 million cigarette.

Afterwards, the annual market share was calculated per company. The excise rate or the price per cigarette was determined based on the best selling type of cigarette from each company. Diversified products were also included in order to see the effect on the market share of the existing companies. Using the data for 2009-15, 63 observations were made.

Excise rate data were obtained from the tobacco excise tariff from the Ministry of Finance in Indonesia. The selling price of cigarettes, taken from the top-selling cigarette brands, and the price obtained by interviewing informants were used. Data on the number of companies per year; they were obtained from the Directorate General of Customs and Excise. Data were also obtained from product diversification gathered from interviews with informants who have observed and understood the kinds of cigarettes.

The cigarette market is known to have big dominant players. In order to see the effect of tax on the large enterprise market share, this study could also be included in the regression of the same model, but only five big companies were included. Econometric measurement was done by developing a study to analyse the determinants of the market share, for this Babic and Kalic (2014) used an econometric model formulated as follows:

$$
\begin{aligned}
& M S_{i \ldots t}=\alpha+\beta_{1} \log \left(C k p h j_{i t}\right)+\beta_{2} \log \left(H j_{i t}\right)+\beta_{3} D v r s_{i t}+\beta_{4} \log \left(P d d k_{t}\right)+\beta_{7} D_{-} A_{i t}+\beta_{8} D_{-} B_{i t} \\
& +\beta_{9} D \_C C_{i t}+\beta_{10} D \_D D_{i t}+\beta_{11} D \_E_{i t}+\beta_{12} D \_F_{i t}+\beta_{13} D \_G_{i t}+\beta_{14} H \_E_{i t}+\beta_{15} D_{-} I_{i t}+e_{i t}
\end{aligned}
$$

In this study, the extent of sensitivity of the number of young people could affect the market share of a company. So, Pddk became Pddk2, which is the number of people aged 15-24 years from 2009 to 2015, considering the large number of people in this age group in the population of Indonesia and also the age of the potential market share for these companies (see Table 1).

\subsection{Structure analysis}

The cigarette industry in Indonesia is categorised in the relative competitive market with a moderate concentration level because the Herfindahl-Hirschman index (HHI) is in the range of 1,112 to 1,376 in 2009-15. The extent of market concentration of each manufacturer in 2009-15, can be described by concentration ratio of the eight largest companies (CR-8) in the industry, with the movement of the concentration ratio as shown in Table 2.

Of the eight major companies, GudangGaram, Sampoerna, and Djarum continue to be ranked the three highest orders of first, second, and third, respectively. Philip Morris Indonesia and Nojorono enlivened the eight largest companies by production of cigarettes in the tobacco 
Table 1. Descriptive variables and research hypotheses.

\begin{tabular}{cll}
\hline Variable & Explanation & Hyp \\
\hline (i) Ms & Market share (percentage) & - \\
(ii) Ckphj & Proportion of excise tax to selling price & - \\
(iii) Hj & Selling price per cigarette & + \\
(iv) Dvrs & Number of variants products per company & + \\
Pddk & Population aged 15 years and above & + \\
(v) Pddk2 & Population aged 15-24 years & \\
(vi) D_A & Dummy variable A \\
(vii) D_B & Dummy variable B \\
(viii) D_C & Dummy variable C \\
(ix) D_D & Dummy variable D \\
(x) D_E & Dummy variable E \\
D_F & Dummy variable F \\
D_G & Dummy variable G \\
(xi) D_H & Dummy variable H \\
D_I & Dummy variable I \\
I & (1,...,.., N) observant \\
$t$ & (1,...,.., t) 2009-15 \\
\hline
\end{tabular}

Source: Authors' compilation

Table 2. CR8 of cigarette companies in Indonesia, 2009-15.

\begin{tabular}{ll}
\hline Year & CR (\%) \\
\hline 2009 & 70.98 \\
2010 & 68.54 \\
2011 & 68.46 \\
2012 & 73.59 \\
2013 & 77.21 \\
2014 & 79.02 \\
2015 & 81.24 \\
\hline
\end{tabular}

Source: Ministry of Finance, Indonesia.

industry from 2009 to 2015. Meanwhile, in a period of seven years, several other companies, such as Asia Tobacco, PDI Tresno, Karyadibya Mahardika, Subur Safe, Bentoel Prima, and new player Indonesia Sampoerna Sembilan, had not previously been included in the eight companies.

\subsection{Behaviour analysis}

The imposition of excise tax on cigarettes is one of the biggest obstacles for these companies because the product's selling price must follow the rules set by the government. Although cigarettes are included in the inelastic goods category, frequent increase in prices does not arise from the cost of production, thus making the companies fear that the demand for cigarettes will decline. The tobacco companies have a variety of ways to overcome this. In terms of price, the companies raise the price of cigarettes before the excise increase, which usually occurs at the beginning of the year, in anticipation of losses that might occur due to rise in cigarette prices the next year, in line with the excise duty increase. In addition, tobacco companies also reduce the cost of production. The use of technology is adopted by tobacco companies, especially companies with large capitalisation, to suppress the average cost of production to achieve economies of scale efficiently. To maintain the affordability of cigarettes, tobacco companies also hire sales agents to sell cigarettes per piece or unit to lure the consumer.

The behaviour of tobacco companies in the responding market can also be determined by product differentiation. In relation to excise tax and the tobacco industry, a strong oligopoly 
structure would make the companies imitate patterns, and observe, and modify various products released by competitors. Cigarette companies generally have several product types, such as SKM, SKT, and SPM, with features that generally include flavour variations to distinguish products between one company and another.

Based on the data from the Directorate General of Customs and Excise, the SKM market share dominated more than $60 \%$ of total cigarettes market share each year (2009-15), and it could reflect that cigarette companies now focus more on premium products. Therefore, SKM has been categorised as a flagship product in line with profits generated. The companies keep producing new brands to give new experiences to their customers by providing new variants of flavours and ensuring a low level of nicotine and tar in response to the growing campaign about health and dangers of smoking. This has been the response amid impact of excise tariff hike to companies' performance and competition in the industry.

In order to become a major player in the tobacco industry, a new company should be able to conduct the same advertisements as competitors. Based on that fact, the government restricted cigarette advertising via Regulation No.109/2012 on the Control of Tobacco Products. Cigarette companies are not allowed to support restricted activities by placing their logo and product names in these. Due to the limited space in the tobacco industry as a result of regulations made by the government, cigarette companies have developed different strategies to keep improving brand awareness by supporting different activities. Currently, the companies implement other strategies, such as promoting musical events or sport activities that have a lot of influence, for promotion by disguising their logo.

\subsection{Performance analysis}

One performance measurement could be seen from the profit; according to Carden (2009), as company's goal, the volume of production is closely linked to income, where both are of paramount importance in making costs of a company's strategic plan. The volume of production is equal to the profit targets to be achieved. Based on the data released by the Directorate General of Customs and Excise, the trend in cigarette production increased from 2009 to 2015, although there was a decline in 2014. This is due to the application of a $10 \%$ cigarette tax in customs tariffs by the government, so the number of the supply manufacturers declined. Examining the dynamics in the tobacco industry through a number of existing productions, it can be said that the cigarette market continues to grow, although there has been a decline.

\section{REGRESSION ANALYSIS RESULTS}

\subsection{Regression results of the entire industry}

From the two models of age groups 15-24 years and 15 years above, we obtained similar results, except for residents. Big differences can be seen where the population variable in the age group 15-24 years has positive and significant results on the market share, whereas in the age group 15 years and obove the results are not significant. These results support further research, where the young population is a potential market for tobacco companies. From the viewpoint of the industry, the introduction of cigarettes to youth as early as possible will make them loyal consumers of the brand.

The results also show that the impact of tax on sales price and the selling price of cigarettes on the market share is elastic, different from existing research results where cigarette consumption is inelastic. Several factors are considered to affect the elasticity:

1. Types of cigarettes: Based on the consumption patterns of smokers, SKM is a substitution of SPM products. The price of SPM cigarettes has a positive influence on demand for SKT cigarettes, where the SPM price increase will cause demand of SKT to increase. Thus, if there is a change in consumption patterns, this will affect the market share of tobacco companies, as the demand of this type of cigarettes will change. 
Table 3. Regression results of the industry.

\begin{tabular}{|c|c|c|c|c|c|c|}
\hline \multirow[b]{2}{*}{ Variable } & \multicolumn{3}{|c|}{ Fixed-Effect model: Aged 15-24 years } & \multicolumn{3}{|c|}{ Fixed-effect model: Aged 15 years and above } \\
\hline & $\mathrm{C}$ & Probability & Result & $\mathrm{C}$ & Probability & Result \\
\hline $\mathrm{C}$ & -685.8813 & 0.0859 & & 31.13330 & 0.0222 & \\
\hline Log-(Ckphj) & $-5.157254 * * *$ & 0.0750 & Significant (-) & $-0.720393^{*}$ & 0.0024 & Significant (-) \\
\hline $\log -(\mathrm{Hj})$ & $-8.847851 * *$ & 0.0189 & Significant (-) & $-1.378618^{*}$ & 0.000 & Significant (-) \\
\hline Dvrs & $0.434621 * * *$ & 0.0652 & Significant $(+)$ & $0.349836^{*}$ & 0.0001 & Significant $(+)$ \\
\hline Log-(Pddk) & $42.60457 * * *$ & 0.0742 & Significant $(+)$ & -0.702992 & 0.2859 & Not significant $(-)$ \\
\hline Dummy A & 11.13600 & & & 9.609224 & & \\
\hline Dummy B & 10.41797 & & & 10.23074 & & \\
\hline Dummy C & 2.951478 & & & 2.080297 & & \\
\hline Dummy D & -5.766594 & & & -6.860440 & & \\
\hline Dummy E & -5.408578 & & & -6.454502 & & \\
\hline Dummy F & 1.685191 & & & 1.892945 & & \\
\hline Dummy G & 3.949806 & & & 5.220653 & & \\
\hline Dummy H & -8.188779 & & & -6.584814 & & \\
\hline \multirow[t]{2}{*}{ Dummy I } & -10.77649 & & & -9.134103 & & \\
\hline & \multicolumn{3}{|c|}{$\begin{array}{l}\text { Adjusted R2 }=0.955913 ; \mathrm{F} \text { statistics }= \\
\quad 90.34336 ; \mathrm{n}=63\end{array}$} & \multicolumn{3}{|c|}{$\begin{array}{l}\text { Adjusted R2 }=0.988944 ; \text { F statistics }= \\
\quad 463.1451 ; \mathrm{n}=63\end{array}$} \\
\hline
\end{tabular}

Note: ${ }^{*} \alpha=1 \%, * * \alpha=5 \%, * * * \alpha=10 \%$.

Source: Authors' compilation.

2. Tastes of young smokers and adult: Young smokers generally prefer cigarettes produced by machines, with a low amount of nicotine and tar. Adult smokers prefer cigarettes with the possibility of a more pronounced flavour.

3. Government policy: One of the implications of excise duty is reduced tobacco consumption. In addition, to support the reduction of tobacco consumption, the government has also made a variety of policies ranging from limiting advertising in media, banning smoking in certain public places, to the latest ban on cigarette sponsorship for education, sports, and music events. Many of the policies have begun to give effects to the increasing awareness of the dangers of smoking.

From those two models (Table 3), different results have been obtained. In the group aged 15-24 years, excise tariff per selling price, selling price, and population do not affect cigarettes companies' market share. In the group aged of 15 years and above, excise tariff per selling price positively affects the market share. From the previous analysis of the market structure, the number of companies in the tobacco industry is known to continue to decrease each year. The shrinkage occurs in small companies that generally produce SK cigarettes. Individuals aged 15 years and above generally consume SKM cigarettes, so when excise tariff hike burdens production costs, the companies can suffer from bankrupty, and their market share will be taken up by a larger company. The selling price for the group aged 15 years and above is elastic. Elasticity at that age is possible because it increases awareness of the dangers of smoking (as described in the previous regression results). As for the impact of the group aged 15 years and above, population growth will reduce the market share of the five major companies because that age is not the primary target market of these companies, as they produce more machines-made cigarettes.

\subsection{Regression sesults of the five major companies}

From those two models, different results have been obtained. In the group aged 15-24 years, excise tariff per selling price, selling price, and population do not affect cigarettes companies' market share. In the group aged 15 years and above, excise tariff per selling price positively affects the market share. From the previous analysis of the market structure, the number of companies in the tobacco industry is known to continue to decrease each year (see Table 4). The shrinkage occurs in small companies that generally produce SKM cigarettes. Individuals aged 15 years and above generally consume SKM cigarettes, so when excise tariff hike 
Table 4. Regression results of five major companies.

\begin{tabular}{|c|c|c|c|c|c|c|}
\hline \multirow[b]{2}{*}{ Variable } & \multicolumn{3}{|c|}{ Fixed-Effect Model: Aged 15-24 years } & \multicolumn{3}{|c|}{$\begin{array}{l}\text { Fixed-Effect model: Aged } 15 \text { years and } \\
\text { above }\end{array}$} \\
\hline & $\mathrm{C}$ & Probability & Result & $\mathrm{C}$ & Probability & Result \\
\hline $\mathrm{C}$ & -322.7474 & 0.2255 & & 72.81254 & 0.0027 & \\
\hline Log-(Ckphj) & -0.581728 & 0.6412 & Not significant (-) & $1.849392 * * *$ & 0.0581 & Significant $(+)$ \\
\hline $\log -(\mathrm{Hj})$ & -4.048809 & 0.1291 & Not significant (-) & $-1.371495^{*}$ & 0.0016 & Significant (-) \\
\hline Dvrs & $0.311782 * *$ & 0.0256 & Significant $(+)$ & $0.369493 *$ & 0.0003 & Significant $(+)$ \\
\hline Log-(Pddk) & 20.52535 & 0.2034 & Not significant $(+)$ & $-2.712215^{*}$ & 0.0321 & Significant (-) \\
\hline Dummy A & \multicolumn{3}{|c|}{8.212542} & \multicolumn{3}{|c|}{7.974007} \\
\hline Dummy B & \multicolumn{3}{|c|}{8.469831} & \multicolumn{3}{|c|}{8.576527} \\
\hline Dummy C & \multicolumn{3}{|c|}{0.495929} & \multicolumn{3}{|c|}{0.324335} \\
\hline Dummy D & \multirow{2}{*}{\multicolumn{3}{|c|}{$\begin{array}{l}-8.713303 \\
-8.465000\end{array}$}} & \multicolumn{3}{|c|}{-8.735417} \\
\hline Dummy E & & & & \multicolumn{3}{|c|}{-8.139453} \\
\hline & \multicolumn{3}{|c|}{$\begin{array}{l}\text { Adjusted R2 }=0.991348 ; \text { Fstatistics }=487.9812 \\
\quad \mathrm{n}=35\end{array}$} & \multicolumn{3}{|c|}{$\begin{array}{l}\text { Adjusted R2 }=0.993787 ; \text { Fstatistics }= \\
\quad 680.8014 ; \mathrm{n}=35\end{array}$} \\
\hline
\end{tabular}

Note: ${ }^{*} \alpha=1 \%,{ }^{* *} \alpha=5 \%, * * * \alpha=10 \%$.

Source: Authors' compilation.

burdens production costs, the companies can suffer from bankruptcy, and their market share will be taken up by a larger company. The selling price for the group aged 15 years and above is elastic. Elasticity at that age is possible because it increases awareness of the dangers of smoking (as described in the previous regression results). As for the impact of the group aged 15 years and above, population growth will reduce the market share of the five major companies because that age is not the primary target market of these companies, as they produce more machines-made cigarettes.

\section{CONCLUSIONS}

Based on the amount of CR8 in the tobacco industry from 2009 to 2015 , the industry is categorised in an oligopolistic market, where there are many players, but only the big players control the market. Moreover, the large companies continue to widen their market share by creating subsidiary or affiliated companies to maintain their position. Throughout 2009-15, the CR8 trend continued to rise, although it saw a decline in 2010 and 2011. However, from the value of HHI, which ranged from 1,254.73 to $1,376.41$ between 2009 and 2015, the tobacco industry is categorised in the relatively competitive market with a moderate concentration level.

The regression results, show that the increase in excise duty does not significantly affect cigarette market share gains. In all companies in the industry, for both the age group 15 years and above and 15-24 years, the proportion of taxes per sale price decreases the market share, as well as the selling price. Elasticity is affected by the types of cigarettes, tastes of young smokers and adults, and the effectiveness of government policies. In the five major companies, the tax per selling price actually increases a company's market share due to higher excise duty rates, so it will reduce the cost of production, but in the long term it will make the company bankrupt. The market share left by the company who cannot survive in the market, taken up by a larger company. The cigarette demand that continues to increase from year to year, in line with the growth of the consumers, makes the company who still survive in the market grow up. Thus, it can be seen that the market share of large companies (in this case five main companies) continues to increase each year.

In addition to taxes, the selling price, product diversification, and the number of people who are potential consumers of cigarettes are other factors affecting a company's market share of cigarettes. Youth are believed to be the largest market because of the increasing population aged 1524 years the cigarette market share could also increase, considering that, at that age, they are smoking for the first time. 


\section{RECOMMENDATIONS}

The government should not hesitate to raise excise tax because it does not affect the companies' performance. This has been proved by the increasing production, the profit generated by companies, as well as the growing market share, especially of large enterprises. Improved performance is also affected by the use of machines, so companies can work more efficiently. On the other hand, the use of machinery in the industry continues to decrease employment. Under these conditions, concern about the declining number of labourers because tax rates continue to rise should not be the government's focus.

Revenue from excise tariffs can be used for the health sector with a more precise amount, not only in revenue-sharing, as it exists today. For example, Thailand applies $2 \%$ of tax rates on the health sector. Health funds have been allocated to the locals. These funds are not only used as compensation for externalities caused by smoking but are also necessary for prevention activities in a more massive movement, given the increasingly young age people become active smokers. In addition, regulations are also important to limit cigarette consumption by adolescents. In terms of employment, excise funds can also be used to gradually shift workers who are no longer absorbed in the cigarette industry as they are being replaced by machines.

\section{RESEARCH LIMITATIONS}

The implementation of excise tariffs on cigarettes has made cigarette manufacturers behave fraudulently, such as by falsifying or even not buying a banderol according to regulations. These circumstances make this research underestimate and not fully cover the demand of cigarettes in the country. In order to obtain more accurate results, this research is expected to estimate production through a comparison between the sales and excise bands. It also needs to conduct a qualitative study on the smoking preferences of young people.

\section{REFERENCES}

Arnett, J. J. \& Terhanian, G. (1998). Adolescents' responses to cigarette advertisements: Links between exposure, liking, and the appeal of smoking. Tobacco Control.

Babic, D. K. \& Kalic, M. (2014). Market share modeling in airline industry: An emerging market economies application. University of Belgrade.

Bates \& Rowell (2008). Tobacco advertising \& youth: Marketing tactics. Available at: tobaccofreekids. org.

Carden, A. (2009). "Profit and production." Quarterly Journal of Austrian Economics, 12-(2).

Herlambang, A. S. (2005). "Pengaruh Kebijakan Tarif Cukai Terhadap Konsumsi Rokok: Sebuah Kajian Kompeherensif" (The Impact of Excise Tax to Cigarette Consumption: a Comprehensive Review), Unpublished master's thesis. University of Indonesia, Indonesia.

Irvan, P. (2012). Sejarah Perkembangan Rokok Kretek di Indonesia (The History of Clove Cigarettes in Indonesia). Available at: http://id.netlog.com/irvandpoetra/blog/blogid $=135510$.

Kuncoro, M. (2007). Ekonomika Industri Indonesia. (Indonesian Industrial Economics) Yogyakarta: Penerbit ANDI.

Learn, N. C. (2006). "Inventions in the tobacco industry" Tar Heel Junior Historia. 46,-(1). Available at: http://www.learnnc.org/lp/editions/nchist-newsouth/4402.

Lian, D. (2015). Southeast Asian Tobacco Control Atlas Second Edition. Southeast Asia Tobacco Control Alliance. Penang, Malaysia: Crown Print Associates.

Rudi, H. (2004). "Policy Analysis of the Impact of Increase in Excise Tariffs on Cigarette Consumption" (Unpublished master's thesis). University of Indonesia. Indonesia.

Sumarno, S. B. \& Kuncoro, M. (2002). Structure, Performance, and Cluster of Clove Cigarettes Industry: Indonesia, 1996-1999. Jurnal Ekonomi dan Bisnis Indonesia.

Surjono, N. D. (2013). "Impact of Advalorem, Specific, and Hybrid Excise System on Cigarette Price and Consumption" (Unpublished dissertation). University of Indonesia. Indonesia.

Tauraz, P. \& Chaolupka, F. J. (2006). The Role of retail prices and promotions in determining cigarette brand market share. Review of Industrial Organization. University of Illinois. 